УДК 343.98

DOI https://doi.org/10.32837/apdp.v0i88.3049

В. В. Арешонков

\title{
ТЕХНІЧНЕ ЗАБЕЗПЕЧЕННЯ ТЕХНІКО-КРИМІНАЛІСТИЧНИХ ДОСЛІДЖЕНЬ У РОЗСЛІДУВАННІ ЗЛОЧИНІВ
}

Постановка проблеми. 3 початку формування криміналістики як самостійної науки та криміналістичної техніки як їі розділу серед науковців ведеться наукова дискусія щодо можливості застосування технічних засобів під час розслідування злочинів, їх різновидів, форм та підстав застосування. Окрім цього, у літературі науковцями вживаються навіть різні поняття, серед яких: технічні засоби; спеціальні технічні засоби криміналістики; криміналістичні засоби; науково-технічні засоби; техніко-криміналістичні засоби тощо. Відповідно, щодо доцільності вживання того чи іншого терміну між науковцями також виникають суперечки.

Стан дослідження. Різні аспекти проблематики, пов'язаної з технічним забезпеченням окремих різновидів техніко-криміналістичних досліджень, розглядали у своїх роботах такі вчені, як Р.С. Бєлкін, В.Г. Гончаренко, О.М. Зінін, А.В. Іщенко, Н.І. Клименко, В.О. Коновалова, В.К. Лисиченко, Н.П. Майліс, І.В. Пиріг, М.В. Салтевський, М.Я. Сегай, Е.Б. Сімакова-Єфремян, В.Ю. Шепітько, М.Г. Щербаковський та інші, проте питання технічного забезпечення техніко-криміналістичних досліджень загалом майже не розглядалось, що пов'язано перш за все із тим, що така категорія є новою для вітчизняної криміналістики. У зв’язку з цим розгляд наявної проблематики технічного забезпечення техніко-криміналістичних досліджень та шляхів вирішення окремих проблем є надзвичайно актуальним.

Мета статті полягає у визначенні поняття та різновидів технічного забезпечення техніко-криміналістичних досліджень, окресленні наявної проблематики в цій сфері, а також визначенні окремих шляхів вирішення наявних проблем.

Виклад основного матеріалу. Поділяючи науково-технічні засоби на техніко-криміналістичні і загально-технічні, В.Г. Гончаренко зазначає: «поняттям «науково-технічні засоби» необхідно охоплювати усі без винятку засоби і методи їх застосування, які використовуються у слідчій роботі, а терміном «техніко-криміналістичні засоби» - технічні засоби, спеціально створені для криміналістичних цілей чи пристосовані для цього шляхом зміни загально-технічних засобів» [1, с. 9-10]. На наш погляд, наукові дискусії щодо застосування різної термінології на позначення технічних засобів, що використовуються під час розслідування, не мають підгрунтя. $€$ цілком зрозумілим поняття «технічні засоби», що не потребує тлумачення. Будь-які технічні засоби та методи їх застосування, що можуть використовуватись під час розслідування кримінальних правопорушень розглядаються у розділі криміналістики - криміналістичній техніці, тобто є техніко-криміналістичними.

Техніко-криміналістичні дослідження являють собою комплекс дій, що неможливо здійснити без належного технічного забезпечення. Поняттю технічного (у нашому розумінні) або техніко-криміналістичного забезпечення розслідування

(C) B. В. Арешонков, 2020 
приділялась увага з боку науковців. Так, Г.І. Грамович техніко-криміналістичне забезпечення визначав як регламентовану «нормативними актами діяльність науково-дослідних, судово-експертних та інших установ, а також відповідних посадових осіб, на яких покладено обов'язок щодо розробки і реалізації комплексу взаємопов'язаних заходів з метою створення оптимальних умов ефективного застосування спеціальних знань і науково-технічних засобів у боротьбі зі злочинністю» [2, с. 37].

В.О. Волинський розглядає техніко-криміналістичне забезпечення як одну 3 приватних криміналістичних теорій, цільовою функцією якої є дослідження закономірностей, спільних наукових передумов і конкретних умов розвитку техніко-криміналістичних засобів і методів, системи їх впровадження в практику боротьби зі злочинністю та використання в цілях запобігання, розкриття і розслідування злочинів. За визначенням автора, «техніко-криміналістичне забезпечення розкриття та розслідування злочинів - це організаційно-функціональна система, спрямована на створення умов постійної готовності служб та підрозділів органів внутрішніх справ до швидкого й ефективного вирішення техніко-криміналістичних завдань, і на практичну реалізацію цих умов з метою отримання, накопичення, обробки криміналістично значимої інформації та її використання в процесі розкриття і розслідування злочинів [3, с. 12].

Враховуючи аналіз думок науковців щодо визначення поняття техніко-криміналістичного забезпечення та з огляду на сутність різновидів техніко-криміналістичних досліджень (пошук, огляд та попереднє дослідження слідів злочину, перевірка об'єктів за криміналістичними обліками та проведення криміналістичних експертиз) маємо надати власне визначення технічного забезпечення техніко-криміналістичних досліджень, під яким ми розуміємо діяльність з постачання суб'єктам проведення техніко-криміналістичних досліджень технічних засобів збирання та дослідження об'єктів, що містять або можуть містити інформацію, яка має значення для розслідування злочинів, та, відповідно, наявність у зазначених суб'єктів таких засобів у певній кількості та певної якості. Як зазначалось раніше, суб'єктами проведення техніко-криміналістичних досліджень є слідчий, детектив, працівник оперативного підрозділу, спеціаліст, експерт. Під збиранням інформації розуміємо її виявлення, фіксацію, вилучення та зберігання.

Загалом технічні засоби в криміналістиці класифікують за різними підставами. Найбільш розповсюдженою є класифікація технічних засобів за джерелом походження. За цим критерієм Є.П. Іщенко науково-технічні засоби поділяє на три групи. До першої він відносить засоби, створені й використовувані тільки в криміналістичній практиці (власне криміналістичні засоби); другу складають засоби, запозичені з інших галузей науки й техніки і пристосовані для криміналістичних цілей; до третьої належать засоби, запозичені з загальної техніки та використовувані без змін [4, с. 32-33]. За класифікацією В.Ю. Шепітька, засоби також поділяються на три групи: 1) взяті без змін з різних технічних і природно-технічних наук; 2) спеціально пристосовані для криміналістичних цілей; 3) спеціально розроблені для цілей криміналістики [5, с. 58]. Наведена класифікація технічних засобів загальноприйнята, не викликає значних дискусій серед вчених-криміналістів та викладена у багатьох підручниках. 
А.А. Саковський наводить класифікацію, розділяючи критерії за «цільовим» та «спеціальним» призначенням. За цільовим призначенням автор поділяє технічні засоби на ті, що використовуються з такими цілями: виявлення, вилучення та фіксація доказів; дослідження речових доказів під час проведення експертиз; для фіксації ходу та результатів слідчих (розшукових) дій; для попередження правопорушень. За спеціальним призначенням автор поділяє технічні засоби на: засоби фотота відео- записуючої техніки; засоби роботи з матеріальними слідами з метою їх виявлення, фіксації та подальшого дослідження; засоби аналітичної роботи; пошукові засоби; збирання, збереження та оброблення інформації; допоміжні засоби. За видом технічних засобів він виділяє: пристрої та апаратуру, інструменти та обладнання, прилади та матеріали, комплекти науково-технічних засобів [6, с. 69-70].

Майже всі науковці також поділяють техніко-криміналістичні засоби залежно від сфери та суб'єкта використання: слідча (використовує слідчий), оперативна (оперуповноважений), експертна (експерти та спеціалісти). Під час проведення техніко-криміналістичних досліджень слідчий, детектив або оперуповноважений, який виконує обов'язки слідчого за його дорученням, найчастіше застосовують нескладні технічні пристрої, що не потребують використання при цьому спеціальних знань, в основному для виявлення, фіксації та вилучення слідів при проведенні слідчих (розшукових) дій. Техніка спеціаліста чи експерта є складнішою, її використання обов'язково потребує володіння спеціальними знаннями і вона застосовується не тільки для збирання, а і для попередніх досліджень об'єктів чи проведення криміналістичних експертиз.

Працівники оперативних підрозділів під час виявлення злочинів до початку розслідування, а також під час проведення негласних слідчих (розшукових) дій за дорученням слідчого використовують так звану оперативну чи спеціальну техніку. Така техніка розглядається теорією оперативно-розшукової діяльності, не використовується під час проведення техніко-криміналістичних досліджень і не входить в предмет нашого дослідження.

На нашу думку, найбільше значення має класифікація технічних засобів за призначенням. 3 огляду на різновиди техніко-криміналістичних досліджень та етапи їх проведення пропонуємо за цим критерієм класифікувати технічні засоби на три групи:

1. Пошуку, огляду та попереднього дослідження об'єктів, що містять інформацію за кримінальним провадженням та можуть стати речовими доказами. Ці технічні засоби використовуються під час проведення техніко-криміналістичних досліджень на місці події, під час обшуку чи освідування.

2. Перевірки об’єктів за криміналістичними обліками. Цю групу технічних засобів складають інформаційні та інформаційно-пошукові системи, що застосовуються під час формування та використання криміналістичних обліків.

3. Експертних досліджень. Технічні засоби цієї групи використовуються експертами в лабораторних умовах (рідше для проведення експертиз на місці події) під час проведення криміналістичних експертиз.

Розглянемо сучасний стан технічного забезпечення техніко-криміналістичних досліджень за запропонованою нами класифікацією. 
Як відмічалось нами раніше, велику інформативність несуть сліди-відображення, але для отримання цієї інформації потрібно застосовувати технічні засоби. Серед всіх найбільш розповсюдженими є сліди рук людини, які зазвичай невидимі чи слабовидимі. Складність технічних засобів, що використовуються для виявлення, фіксації та вилучення слідів, значною мірою залежить від виду самих об’єктів, їх стану та властивостей. Сліди рук виявляються фізичним чи хімічним способом. Основним з фізичних способів є обробка поверхні порошками, які розрізняються за кольором та магнітними властивостями.

Цікавими є наукові розробки Черкаського НДЕКЦ з використання магнітного порошку «Трифолін» для виявлення слідів. Цей порошок має колір від темно-коричневого до чорного та зазвичай використовується у сільському господарстві для очищення насіння від бур'янів та інших домішок. Проведені співробітниками центру (В.В. Кожевніков) дослідження дозволяють зробити висновки про можливість використання цього порошку з огляду на якість виявлених слідів та можливість їх подальшого біологічного та молекулярно-генетичного дослідження [7, с. 272-275].

Однак найбільш сучасним технічним засобом для фіксації та візуального дослідження виявлених слідів є візуалізатори, наприклад “Scene Score RUVIS 29 MP”. Передусім він використовується для пошуку невидимих відбитків пальців рук як безпосередньо на місці події, так і в лабораторних умовах без обробки порошками та реактивами на гладких непористих поверхнях, у тому числі різнокольорових. Робота приладу заснована на використанні технології формування зображення за відбитим ультрафіолетовим випромінюванням. Він здатен вибірково підсилювати короткохвильове ультрафіолетове випромінювання та ігнорувати всі інші довжини хвиль світла.

Серед технічних засобів потрібно зазначити їх спеціалізовані комплекти. На практиці інспектори-криміналісти слідчих відділів поліції використовують як власноруч укомплектовані валізи, так і уніфіковані, що виготовляються на спеціалізованих підприємствах. Наприклад, підприємства «Експертні системи» (м. Київ), «Інжен» (м. Ніжен) виготовляють криміналістичні валізи: уніфіковані криміналіста (СВ-1, СВ-2, Криміналіст НП, ВК-1), для вилучення об'ємних слідів взуття та шин автотранспорту (ВТ-2), для виявлення та вилучення слідів біологічного походження (ХБ-2), для виявлення та вилучення пилових слідів (ПС-1), для огляду місця пожару (ВП-1, ВП-1М), балістичні (БВ-10), для огляду місця вибуху (BВ-1), для пошукових робіт (ВК-4, НП-1) тощо. Комплектація криміналістичних валіз і наборів містить не тільки набір основних інструментів, необхідних для вилучення слідів під час огляду місця події, але й комплекти спеціальних наборів для попереднього дослідження об’єктів.

На основі методів спектроскопії розроблено пристрої для експрес-аналізу виявлених на місці події хімічних речовин. Серед приладів такого класу можна виділити такі: Gemini - портативний аналізатор, в якому інтегровані раманівська та інфрачервона технології молекулярної спектроскопії; FirstDefender - раманівський спектрометр; TruDefender - FTIR-аналізатор; TruNarc -спектрометр для ідентифікації наркотичних речовин та прекурсорів. Спектрометри дозволяють отримати надійні результати з ідентифікації невідомих речовин протягом декількох секунд. 
Прилади для аналізу властивостей і ознак об’єктів найбільш поширені та різноманітні. Серед них можна виділити прилади та пристрої для: мікроскопічного аналізу: лупи, мікроскопи; дослідження у невидимих зонах спектру (ультрафіолетові освітлювачі, електронно-оптичні перетворювачі, $\alpha$-, $\beta$-випромінювачі); установки дляадсорбційно-люмінесцентного, мас-спектроскопічного, хроматографічного, емісійного, електрографічного, спектрографічного, радіоактиваційного аналізів тощо.

Характерним для нових інформаційних технологій є персоналізація технічних засобів, створення локальних комп'ютерних мереж і багаторівневих систем обробки даних, організація автоматизованих робочих місць спеціалістів.

Активну участь у створенні технічних засобів проведення техніко-криміналістичних досліджень та розслідування злочинів загалом приймає і Національна академія внутрішніх справ. Так, за період з 1997 р. до 2019 р. академією отримано 72 патенти України, у тому числі 24 патенти на винаходи, 29 патентів на корисні моделі, 6 патентів на промислові зразки, а також отримано значну кількість свідоцтв про реєстрацію авторського права на твір, серед яких 18 на Інформаційно-довідкові програми (AРM) - «Автоматизоване робоче місце слідчого», «Робоче місце експерта з трасологічних досліджень», «Робоче місце експерта з техніко-криміналістичного дослідження документів», «Робоче місце експерта з судово-балістичних досліджень» та інші.

У окремих розробках активну участь взяв безпосередньо і автор статті, серед яких: «Комп'ютерна програма «Автоматизована інформаційно-пошукова система «Стрілецька нарізна вогнепальна зброя та патрони до неї» (Свідоцтво № 80626 від 30.07.2018р.), «Лінійка трафаретна криміналістична для огляду місця події» (Патент на промисловий зразок № 35937 від 26.12.2017р.), «Контейнер для об'єктів біологічного походження» (Патент на корисну модель № 116198 від 10.05.2017р.), «Пристрій для руйнування вибухонебезпечних предметів у важкодоступних місцях" (Патент на корисну модель № 110370 від 10.10.2016р.), «Спосіб ідентифікації гладкоствольної вогнепальної зброї за слідами каналу ствола на елементах спорядження набоїв» (Патент на корисну модель № 87289 від 10.02.2014р.), «Спосіб маркування гладкоствольної вогнепальної зброї» (Патент на винахід № 100769 від 25.01.2013 р.) та інші.

Для проведення експертних досліджень важливу роль відіграють сучасні мікроскопи: оптичні, електронні, рентгенівські, мультифотонні тощо.

Для проведення порівняльних балістичних, трасологічних досліджень застосовуються порівняльні мікроскопи. Наприклад, на оснащенні Київського НДІСЕ знаходиться порівняльний мікроскоп “Vision X PROGECTINA FG”, що добре зарекомендував себе з огляду на його характеристики у частині діапазону збільшень, системи освітлення, параметрів цифрової камери та ергономіки [8, с. 483].

Серед автоматизованих програмних комплексів, що використовуються сьогодні під час проведення техніко-криміналістичних досліджень, необхідно зазначити програмне забезпечення для ведення дактилоскопічного обліку Автоматизована інформаційно-пошукова система (далі - АІПС) «Дакто-2000», за допомогою якої здійснюється ідентифікація відбитків в автоматичному режимі. Автоматизована система портретної ідентифікації «Портрет» призначена для створення опера- 
тивних відеотек обсягом кілька десятків мільйонів зображень. АІПС призначена для централізованого обліку та розшуку осіб і суб'єктивних портретів.

Програмний комплекс для ідентифікації людини за голосом та мовленням «SIVE v.8.2» використовується для визначення та порівняння параметрів голосу мовця для відображення статистичного розподілу відповідних параметрів на діаграмах і розрахування коефіцієнту кореляції між цими діаграмами.

Аналізом переваг сучасної техніки, призначеної для експертних досліджень, підтверджується перспективність розвитку цього напряму. Нами зазначено лише окремі наукові досягнення у напряму розвитку експертної техніки. Безумовно, перерахувати всі сучасні технічні розробки в одній статті неможливо.

Висновки. Водночас, розглянувши технічне забезпечення техніко-криміналістичних досліджень на кожному з етапів, а також здійснивши аналіз результатів анкетування, проведеного нами серед працівників слідчих підрозділів Національної поліції України та працівників Експертної служби МВС України, все ж таки можна визначити основні проблеми, що існують сьогодні у цьому напряму, а саме:

- недостатність технічного забезпечення техніко-криміналістичних досліджень, особливо доекспертних (на цьому наголосили $87 \%$ респондентів);

- низький рівень технічного забезпечення окремих підрозділів з техніко-криміналістичного забезпечення органів досудового розслідування Національної поліції у порівнянні з експертними підрозділами, наслідком чого є недоотримання початкового матеріалу для проведення послідуючих лабораторних техніко-криміналістичних досліджень (на цьому наголосили $72 \%$ респондентів);

- інколи нерівномірність забезпечення технікою слідчих та експертних підрозділів окремих регіонів України, більше зосередження технічних засобів у обласних центрах порівняно з регіональними та кущовими підрозділами;

- недостатня кількість вітчизняних наукових розробок криміналістичної техніки, відсутність комплексного підходу у цьому напряму.

Для вирішення зазначених проблем пропонуємо здійснення таких заходів:

- здійснити моніторинг рівня технічного забезпечення підрозділів, що проводять техніко-криміналістичні дослідження, та більш раціонально розподіляти кошти на придбання техніки, а також збільшити фінансування на закупівлю обладнання загалом;

- визначити перспективні напрями впровадження та використання техніки для проведення техніко-криміналістичних досліджень на кожному з етапів. Такими напрямами ми вважаємо стосовно засобів пошуку, огляду та попередніх досліджень впровадження: спеціалізованих комплектів для вирішення конкретних завдань техніко-криміналістичних досліджень, засобів безконтактного пошуку слідів, автоматизованих програм вирішення невідкладних окремих видів попередніх досліджень, засобів експрес-аналізу речовин. Для вдосконалення перевірки за криміналістичними обліками: модернізація існуючих АІПС; запровадження нових АІПС, заснованих на біометричних параметрах людини, штучному інтелекті та інших технологічних інноваціях; вдосконалення мережі обміну інформацією криміналістичних обліків. Для вдосконалення проведення експертиз необхідно: 
забезпечити сучасною технікою окремі види досліджень, за відсутності вітчизняних розробок здійснювати ії придбання у провідних закордонних виробників, приділити увагу розробці автоматизованих комплексів для проведення експертиз;

- продовжити роботу з стимулювання вітчизняних наукових розробок, для чого на державному рівні потрібно створити творчі колективи науковців Науково-дослідних установ, навчальних закладів та практичних працівників, які проводять техніко-криміналістичні дослідження. Поряд з розробкою нових технічних засобів, здійснити впровадження в практику вже наявних розробок.

\section{Jimepamypa}

1. Гончаренко В.И. Научно-технические средства в следственной практике. Київ : Вища школа, 1984. $149 \mathrm{c}$.

2. Грамович Г.И. Проблема теории и практики эффективного применения специальных знаний и научно-технических средств в раскрытии и расследовании преступлений : автореф. дис. ... докт. юрид. наук : 12.00 .09 . Киев, 1989.39 с.

3. Волынский В.А. Технико-криминалистическое обеспечение раскрытия и расследования преступлений. Пособие. Москва : Изд-во ВНИИ МВД РФ, 1994. 80 с.

4. Ищенко Е.П. Классификация научно-технических средств, используемых на предварительном следствии. Теория и практика собирания доказательственной информации техническими средствами на предварительном следствии : сб. науч. тр. Киев : НИ и РИО КВШ МВД СССР им. Ф.З. Дзержинского, 1980. С. $30-36$.

5. Глібко В.М., Дудніков А.Л., Журавель В.А. та ін. Криміналістика: підруч. для студ. юрид. спец. вищ. закл. освіти / за ред. В. Ю. Шепітька. Київ : Вид. Дім «Ін Юре», 2001. 684 с.

6. Пясковський В.В., Чорноус Ю.М., Іщенко А.В., Алєксєєв О.О. та інші. Криміналістика : підручник. Київ : «Центр учбової літератури», 2015. 544 с.

7. Кожевніков В.В. Використання магнітного порошку «Трифолін» для виявлення слідів рук. Актуальні питання судової експертологї, криміналістики та кримінального процесу : мат. міжн. наук.-практ. конф. (м. Київ, 5.11.2019 р.) / за заг.ред. О.Г. Рувіна, Н.В. Нестор; уклад. О.І. Жеребко, А.О. Полтавський, О.В. Юдіна. Київ : КНДІСЕ Мінюста України, 2019. С. 271-275.

8. Рувін О.Г. Актуальні питання розвитку судової експертизи на прикладі Київського науково-дослідного інституту судових експертиз Міністерства юстиції України. Актуальні питання судової експертології, криміналістики та кримінального процесу : мат. міжн. наук.-практ. конф. (м. Київ, 5.11.2019 р.) / за заг.ред. О.Г. Рувіна, Н.В. Нестор; уклад. О.І. Жеребко, А.О. Полтавський, О.В. Юдіна. Київ : КНДІСЕ Мінюста України, 2019. С. 482-486.

\section{Анотація}

Арешонков В. В. Технічне забезпечення техніко-криміналістичних досліджень у розслідуванні злочинів. - Стаття.

Стаття присвячена вивченню проблематики, пов'язаної з технічними засобами, які використовуються при проведенні техніко-криміналістичних досліджень. У ній наголошується на тому, що наукові дискусії щодо застосування різної термінології на позначення технічних засобів, що використовуються під час розслідування злочинів (спеціальні технічні засоби криміналістики; криміналістичні засоби, науково-технічні засоби тощо), не мають підгрунтя, адже є цілком зрозуміле поняття «технічні засоби», що не потребує тлумачення. На основі аналізу думок науковців надано власне визначення технічного забезпечення техніко-криміналістичних досліджень, під яким розуміється діяльність з постачання суб'єктам проведення техніко-криміналістичних досліджень технічних засобів збирання та дослідження об’єктів, що містять або можуть містити інформацію, яка має значення для розслідування злочинів, та, відповідно, наявність у зазначених суб'єктів таких засобів у певній кількості та певної якості. У статті наголошується, що найбільше значення для техніко-криміналістичних досліджень як практичної діяльності має класифікація технічних засобів за призначенням. 3 огляду на різновиди техніко-криміналістичних досліджень та етапи їх проведення, запропоновано за цим критерієм класифікувати технічні засоби на три групи: 1) пошуку, огляду та попереднього дослідження об’єктів, що містять інформацію за кримінальним провадженням та можуть стати речо- 
вими доказами. 2) перевірки об’єктів за криміналістичними обліками. 3) експертних досліджень. Розглянуто сучасний стан та перспективні напрями технічного забезпечення техніко-криміналістичних досліджень за запропонованою класифікацією. На основі цього визначено основну проблематику технічного забезпечення техніко криміналістичних досліджень, а саме: недостатність технічного забезпечення техніко-криміналістичних досліджень, особливо доекспертних; низький рівень технічного забезпечення окремих підрозділів з техніко-криміналістичного забезпечення органів досудового розслідування Національної поліції порівняно з експертними підрозділами, наслідком чого є недоотримання початкового матеріалу для проведення послідуючих лабораторних досліджень та інші. Запропоновані окремі шляхи вирішення зазначеної проблематики.

Ключові слова: криміналістична техніка, техніко-криміналістичні дослідження, криміналістичні експертизи, технічні засоби, технічне забезпечення.

\section{Summary}

Areshonkov $V . V$. Technical safety of technical-forensic research in crime investigation. - Article.

The article is devoted to the study of issues related to technical means used in technical-forensic research. It emphasizes that scientific discussions on the use of different terminology in the designation of technical means used in the investigation of crimes (special forensic tools; forensic tools, scientific and technical means, etc.) have no basis - there is a clear concept of technical means, which does not require interpretation. Based on the analysis of scientists' opinions, the definition of technical support of technical-forensic research is given, which means the activity of supplying subjects of technicalforensic research with technical means of collecting and researching objects that contain or may contain information relevant to the investigation crimes and accordingly, the presence of these entities of such means in a certain quantity and a certain quality. The article emphasizes that the greatest importance for technical-forensic research as a practical activity is the classification of technical means by purpose. Given the types of forensic investigations and the stages of their conduct, it is proposed to classify technical means into three groups according to this criterion: 1) search, inspection and preliminary investigation of objects that contain information on criminal proceedings and can become material evidence; 2) inspections of objects according to forensic records; 3) expert research. The current state and promising areas of technical support of technical-forensic research according to the proposed classification are considered. Based on this, the main issues of technical support of technical-forensic research are identified, namely: in general, the lack of technical support for forensic research, especially pre-expert; low level of technical support of some units for technical and forensic support of pre-trial investigation bodies of the National Police in comparison with expert units, resulting in a lack of initial material for subsequent laboratory tests and others; insufficient number of domestic scientific developments in forensic science, lack of a comprehensive approach in this direction. Some ways to solve this problem are proposed.

Key words: Forensic equipment, technical-forensic research, forensic examinations, technical means, technical support. 